MARIJANA HAMERŠAK

\title{
Between supporting and reparting: Grassrouts textual responses to the pushbacks at the fringes of EU
}

Intersections. EEJSP

7(2): 49-72.

DDI: 10.17356/ieejsp.v7i2.752

http://intersections.tk.mta.hu

[marham@ief.hr] (Institute of Ethnology

and Folklore Research, Zagreb)

\begin{abstract}
In response to the 2015 mass mobilities disruption of the European Union border control regime, numerous self-organized, pro-migrant ad hoc solidarity groups proliferated across Europe. Depending on the local, national, and migratory contexts, these groups employed different methods and practices to support the people on the move and to challenge the inefficient, bureaucratized, discriminatory, and securitized modes of action of official, state, and humanitarian actors. Some practices that were developed in this framework of grassroots or vernacular humanitarianism with strong solidarity and a volunteer dimension (Brković, 2017; 2020; McGee \& Pelham, 2017; Rozakou, 2017; Sandri, 2018) outgrew the initial crisis context and evolved over time into distinctive formats of response to the border restrictions, exclusions, and violence. One of them is still today a lasting practice of reporting of pushbacks by grassroots groups active at different locations on the southeastern territorial fringes of the EU. After reviewing the relevant literature and outlining the grassroots, selforganized, humanitarian, and human rights background of pushback reports and reporting practices, the author focuses on these reports as a form of writing. Interest in the style, narrative structure, and positionality of these reports opens questions of their parallels with ethnographic inquiries.
\end{abstract}

Keywords: Balkan migratory trail, ethnography, grassroots pro-migrant groups, humanitarianisms, human rights reporting, pushbacks

\section{Introduction}

The year 2015 can be understood as historical for the migration in Europe for several interconnected reasons. For most, it will be remembered for the dramatic media images of endless groups and columns of refugees heading from Greece to the center of the European Union. For others, the year will be remembered for mass mobilities disruption of the repressive border control regime and in actu demonstration of the agency and the power of the movements of migration. For some, it will also be remembered for mass spontaneous citizen engagement in diversified humanitarian assistance and embodied in the images 
of, for example, people who gathered at the Munich train station to welcome refugees or citizen-volunteers helping them on the shores of Greek islands.

In Croatia people of different ages and with different personal histories and social backgrounds were also spontaneously arriving at the border crossing or checkpoints, to share food, offer a lift, provide information, or support newcomers in some other way (see e.g. Župarić-Iljić \& Valenta, 2018, pp. 143-144). Anyone in mid-September 2015 at the Croatian capital Zagreb train or bus stations, or several weeks later at the makeshift border crossings on the green border with Serbia or Slovenia (such as Bapska on the border with Serbia or Ključ Brdovečki on the border with Slovenia) could observe vibrant citizen help and sympathy for the people on the move. Only in Zagreb within just a few weeks a dozen ad hoc initiatives and groups of different scales formed. Some of them assembled hundreds or more individuals, or even a notable number of civil society organizations and informal collectives (see e.g. Bužinkić, 2018), while some consisted of only a few close friends, colleagues from work or random acquaintances. Some were vocal in advocating for political change, while others were primarily interested in providing aid, making sandwiches, and collecting and distributing clothes. Some were composed of locals or those from nearby cities, while others were more national or even transnational.

Activities of these groups were fostered by divergent modes: personal and professional contact, history of common activist or related engagement, as well as by social media group exchanges and public calls. In these first spontaneous gatherings, differences among mostly self-organized supporters seemed obscured and power relations minimal, although some of the actors very quickly gained more dominant positions, depending on a range of reasons, varying from their habitus to group dynamics. Some of these groups grew with time into formal organizations active even today, some continued to act informally, some transnationally, some merged, some switched locations or interests, some further atomized, and some simply shrank as the movement of people shifted in another direction or became isolated once mobile detention of the Croatian section of the Balkan refugee corridor (Hameršak \& Pleše, 2018b) was fully established at the end of 2015.

On the following pages, I would like to outline the recent literature about the phenomena of self-organized pro-migrant citizen initiatives and groups in the critical months of 2015 and 2016, as well as to analyze the commitment of self-organized groups and initiatives to document and denunciate border violence at the external EU border, in particular, pushbacks and deportations to neighboring non-EU countries. Following my previous research about the Croatian section of the Balkan refugee corridor (Hameršak \& Pleše, 2017; 2018a; 2018b) and Croatia's direct involvement in pushback operations since then, this paper focuses on the Croatian context in the period from the Balkan corridor and the beginning of 2016 until today.

Although my deep involvement in the context, my participation in the collective writing of several such reports, as well as my long-term ethnographic research and activist engagement in the field, informed my approach and my insights, due to a plethora of ethical and methodological, personal and professional reasons, the interpretation that follows is not ethnography or autoethnography. It is, first of all, an exploration of texts of published reports and texts surrounding them. Circumventing urgent, but already at least informally tackled problems of (non)authoritativeness of some of these reports, their sometimes imprecise or incomplete representations, their multiple revisions and textual instability, as

INTERSECTIONS. EAST EUROPEAN JOURNAL OF SOCIETY AND POLITICS, 7(2): 49-72. 
well as the galloping problem of criminalization of groups and individuals involved in their production, this essay strives to approach pushbacks reports as a form of writing and to sketch their parallels with humanitarian agendas, human rights reporting, and ethnographic inquiries.

\section{Grassroots pro-migrant supporting mobilization research}

Mass citizen aid or self-organized-often spontaneously initiated-humanitarian engagement on the margins of established or in the official systems of help in the making is not a historically new phenomena, nor is it limited to the context of migration (see Brković, 2017; Fechte \& Schwittay, 2019; Hamann \& Karakayali, 2016, p. 74). Nevertheless, it only recently started to occupy broader research attention, often in relation to the events of 2015. A growing literature on the subject promptly dubbed this phenomenon as, to borrow from the titles of some recently published research volumes and special issues, 'solidarity mobilizations in the "refugee crisis"' (della Porta, 2018), 'migrants' and solidarity struggles' (Birey et al., 2019), 'citizen initiatives for global solidarity' (Schulpen \& Huyse, 2017) or 'refugee protection and civil society in Europe' (Feischmidt et al., 2019) etc. In the same context terms such as 'volunteer humanitarianism' (Sandri, 2017), 'solidarity humanitarianism' (Rozakou, 2017), 'subversive humanitarianism' (Vandevoordt, 2019) or 'grassroots humanitarianism' (McGee \& Pelham, 2018) were introduced in order to highlight different aspects and specific manifestations of the phenomenon known also as 'everyday humanitarianism' or 'vernacular humanitarianisms' (Brković, 2016; 2017; 2020). Within that framework of interest, specific countries, like Greece (e.g., Cabot, 2019; Rozakou, 2016), or locations such as Calais (e.g., Agier et al., 2019; Sandri, 2018), Brussels (e.g., Vandevoordt, 2019), Budapest (e.g., Kallius et al., 2016) or Belgrade (e.g., Cantat, 2020; Jovanović, 2020; Milan, 2019) became places of often ethnographically informed research about selforganized citizen pro-migrant mobilization. Work of pro-migrant groups active along the Balkan migratory trail, such as the Welcome! Initiative (Croatia), Second Home (Slovenia) or the organization Youth for Refugees (Serbia) was also promptly addressed in the literature (e.g., Bužinkić, 2018; El-Shaarawi \& Razsa, 2019; Kurnik \& Razsa, 2020). Their positioning within local contexts, especially in relation to the 1990s war, postwar and antinationalist struggles was discussed, backing the conclusion about the 'Balkan route as a history of old or ad hoc established collectives of independent volunteers' (Kurnik, 2015: 239).

Although research of the Croatian context mainly focused on the work of large-scale 'humanitarian enterprise' (Pozniak, 2020; see Hameršak \& Pleše, 2017; 2018b; Pozniak, 2019; Župarić-Iljić \& Valenta, 2019) that dominated the highly professionalized and securitized Croatian section of the refugee corridor, grassroots engagements related to that context also found their place in the literature. Besides the already mentioned study about Welcome! Initiative, here one should mention in depth (auto)ethnographic accounts on volunteering in the context of the same initiative in the transit camps along the corridor (Grubiša, 2018; Jambrešić Kirin \& Škokić, 2018), as well as vignettes and sketches of citizen assistance scattered across ethnographically founded literature about the corridor (see e.g., Hameršak \& Bužinkić, 2018; Župarić-Iljić \& Valenta, 2019).

In 2015, as well as in the following years, differences between grassroots pro-migrant

INTERSECTIONS. EAST EUROPEAN JOURNAL OF SOCIETY AND POLITICS, 7(2): 49-72. 
groups active at the outskirts of Europe and in the heart of the continent were distributed along the lines of ad infinitum divergent local and national historical and contemporary contexts, experiences, and power relations, as well as along, for example, different realities, aims and struggles of the migratory movements they support. Nevertheless, two general specifics of initiatives at the fringes of EU could be observed: the first is related to the international dimension of the groups at hand and the second is related to these groups' extensive and specialized textual report production. The following paragraphs explore if and how these specifics have been addressed in the literature and manifested on the ground.

The first, the international dimension of pro-migrants grassroots grouping along the migrant trail, at the fringes of the EU, can be connected to a variety of motives and factors. Media coverage of the 'crisis', the atmosphere of change and welcoming, hyper-mobility of young people of the West, as well as geographical proximity (see Cantat, 2020, p. 107; Fechter \& Schwittay, 2019, p. 1772) fostered occasional or longer engagements of citizens mainly from central EU countries in the long-distance aid activities in transit hubs along the main migratory pathways at the outskirts of the EU. As mentioned on the marginalia of the literature about welcoming refugees, 'some volunteers from Southern Germany and Austria [...] went directly to Hungary or Croatia to pick up refugees' (Hamann \& Karakayali, 2016, p. 75), while others went to stay for a few days, weeks or months and offer practical help on the ground. In sum, individuals and groups from mostly central EU states were arriving (self-organized or attached to small NGOs) in countries along transitory pathways, such as Greece, Serbia, or Croatia, with their 'know-how', donations, tents, vans, equipment, and funds for new supplies, joining organizations on the ground or working independently and helping out by, for example, installing improvised distribution spots or outdoor kitchens.

At least in Croatia and Serbia, the international background or the foreignness of some of the grassroots groups was highlighted already in the names they quickly obtained in local contexts. For example, a volunteer named as The Swedish Chef, a 27-year-old chef from Lund, Sweden, ${ }^{1}$ prepared meals for refugees for weeks at the previously mentioned ad hoc border-crossing with Serbia, in Bapska, Croatia, while the group (self)named Czech Team was for months engaged only a few kilometers further in the transit camp Adaševci in Serbia and after 2018 also in Bosnia and Herzegovina. The so-called Hungarians, a group of several people coming from Hungary, were at Ključ Brdovečki-another previously mentioned improvised border-crossing installed in that period and closed after the transit redirected directly to Slovenia. In Dobova in Slovenia, two Austrian volunteers who were called 'the couple from Austria', established an aid tent at the train station for several weeks. ${ }^{2}$ After the full closure of the corridor in Spring 2016 the engagement of international groups was reduced significantly in Croatia-an EU country determined to have 'closed border'

\footnotetext{
See https://www.unhcr.org/news/stories/2015/9/56ec1eb218/swedish-chef-serves-hot-meals-refugees. html.

2 The arrival of volunteers and activists from other countries to countries along the Balkan migratory pathway in that period is acknowledged in the literature about the situation along the Balkan corridor and after (Cantat, 2020, p. 107; Jovanović, 2020, pp. 131-132, et passim), although rarely for Croatia where international and independent volunteers are eventually marginally mentioned, as for example, in the map of first 'reception' sites which refers to an 'improvised outdoor kitchen from German volunteers' (Larsen et al., 2015, p. 36).
}

INTERSECTIONS. EAST EUROPEAN JOURNAL OF SOCIETY AND POLITICS, 7(2): 49-72. 
politics by any means. These politics repelled potential supporters to contexts that may seem as less hostile environments toward solidarity assistance to migrants, first of all to border areas of neighboring non-EU countries such as Serbia and also Bosnia and Herzegovina after 2018 (see Stojić Mitrović et al., 2020, pp. 56, 65, 78, et passim).

Cultural, political and class biases of these (mostly) self-organized international or transnational groups engaged at the fringes of EU were very diverse-some of them being close to what has been described as MNGOs (my own NGO), personalized aid initiatives in the Global South burdened with the legacies of interconnections between humanitarian aid and colonial administration (Fechter \& Schwittay, 2019, p. 1770; see Schulpen \& Huyse, 2017), while other self-organized groups had their background rooted in older European anti-racist, anti-restrictionist and pro-migrant activism inclined toward transnational spheres of action (Cantat, 2015; Schneider \& Kopp, 2017; Stierl, 2019, p. 47; Walters, 2006). In practice, these different lines of engagement merged, accompanied sometimes by tensions and the production of hybrids, as noted in the reflections of one of these groups: "The so-called "Balkanroute" [...] seems to have turned into the place to be for emancipatory left German activists. [...] Within the German left, more and more car convoys aimed at transporting people across borders as well as kitchen collectives got organized and headed to Hungary, Serbia, Greece or Macedonia' (ReflActionist, 2016). In an effort to distance themselves from the 'voluntourism' and 'holidarity', as it is critically labeled, but also to address their own positionality, this group defined their position as that of 'activist tourists' (ReflActionist Collective, 2016).

\section{Grassroots groups textual engagements: Reporting pushbacks}

The second easily discerned point of differentiation between grassroots groups active in the core of the EU and countries along the Balkan migratory trajectory in 2015 and after is related to the later focus on documenting and reporting border violence or, more precisely, to the production of so-called 'pushback reports. ${ }^{3}$ The pushback reports call for analytical engagements and contextualization not only as a specific format of the grassroots involvement at the fringes of EU but also as probably the most comprehensive, although not always most reliable, source of data about pushbacks from Croatia and neighboring countries at the moment. As both a form of documentation and paradigmatic artifacts of modern knowledge practices (see Riles, 2006, p. 2) and as a form of vernacular or 'ordinary' people writing (see Lyons, 2010), they furthermore seem to be relevant foci of discussion.

The first reports about pushbacks from Croatia were published in early 2016 (Banich et al., 2016a; Refugees et al., 2016) when the Balkan refugee corridor was still functioning, while official narratives of efficient and humanitarian fast-track transit of refugees

\footnotetext{
Textual production of grassroots groups in Croatia was of significant local and regional importance from the first days of mass arrivals in 2015. Two of the largest and most prominent Croatian grassroots organizations, or collectives in the respective period, Are you Syrious? and Welcome! Initiative, regularly reported via social media about the situation on the ground and along the migratory path. Reporting at first was daily or even more often, while after the closure of the corridor it was weekly or every few days, but still regularly, being a stable source of information until today. Besides these general reports that served as both first-hand information about the situation on the ground, as well as a mobilizing tool, a number of grassroots groups situated in Croatia and neighboring countries in parallel specialized in the production of pushback reports which are the focus of this article.
}

INTERSECTIONS. EAST EUROPEAN JOURNAL OF SOCIETY AND POLITICS, 7(2): 49-72. 
through Croatia were yet widely perpetuated (Documenta, [2015]; European Economic and Social Committee, 2016; Larsen et al., 2016; Šelo Šabić \& Borić, 2016). These reports were followed by reports about pushbacks from other countries along the corridor: Austria, North Macedonia, and Slovenia (Moving Europe, 2016b; 2016c; 2016d). Over the following months, new reports about border violence in the Croatian section of the corridor were published (Banich et al., 2016b; Inicijativa Dobrodošli, 2016). In 2017, after reports by some previously mentioned transnational (Moving Europe, 2016e) and local grassroots groups (Inicijativa Dobrodošli! \& Are you Syrious, 2017a; 2017b; 2017c), prominent international human rights and humanitarian organizations (Human Rights Watch, 2017; Médecins Sans Frontières, 2017; Belgrade Centre for Human Rights etc., 2017) started to extensively report about pushbacks from Croatia.

From then on dozens of grassroots collectives located in Serbia, Bosnia and Herzegovina, Croatia, and Slovenia and in more or less close everyday contact with people on the move engaged in reporting pushbacks-most often in English, signaling the international or transnational dimension of this reporting practice. The most active or at least most systematic in reporting were international, often transnational self-organized groups situated at the outskirts of Serbia and the Bosnia and Herzegovina border with Croatia, where they would see and encounter people upon their pushback from EU member states. In 2018 when the migratory pathways proliferated also across Bosnia and Herzegovina grassroots reports of pushbacks started to be produced even with more vigor, in bigger numbers, by more groups. ${ }^{4}$ The year 2019 saw the stabilization of reporting procedures and practices with efforts directed toward advocacy and dissemination of report findings in divergent formats, including in the form of maps (see Push-Back Map and Border Violence Monitoring Network Testimonies Database), which was more or less the situation before the 2020 and COVID-19 pandemic which at first resulted in the reduction of different activities, including grassroots reporting. Due to extensive and divergent reporting and advocacy work, supported by media coverage and investigations, pushbacks along the so-called Balkan route became a hallmark of relentlessness and violence of the re-stabilized European border regime (Hess \& Kasparek, 2017) at the southeastern fringes of the EU.

The reports published by grassroots groups active in Croatia and neighboring countries

\footnotetext{
Groups involved in reporting pushbacks, their number and names, can be roughly determined by the insight into the changes of the paratext (Genette, 1997), textual and nontextual elements surrounding the text (cover, introduction etc.), of one of the probably the longest-lasting periodical publication of pushback reports: monthly Illegal Pushback [Push-backs] and Violence Reports and since March 2020 Balkan Region reports (No Name Kitchen etc., 2018, 2019; Border Violence Monitoring Network 2019, 2020a, 2020b, https:/www.nonamekitchen.org/en/violencereports/; https://www.borderviolence.eu/category/monthly-report/page/2/). These reports were published mostly on the monthly basis by No name Kitchen and other groups (Border Violence Monitoring, [re:]ports Sarajevo, Escuela con Alma, Ljuta Krajina - SOS - Team Kladuša etc.) until July 2019 when Border Violence Monitoring Network this group is part of became the publisher. Starting from the report from June 2018 these reports are available via webpages of No Name Kitchen (https://www.nonamekitchen.org/en/violence-reports/) with latest report from January 2020 and Border Violence Network (https://www.borderviolence.eu/category/monthly-report/) with reports from December 2018-March 2019 till today (October 2020). Monthly reports issued from 2017 to May 2018 are not available online but were taken into the account in this paper. Changes in the title of these reports provide insight into the steadily spreading of the territory they cover, from reports from one specific location or border town such as Šid or Velika Kladuša to the reports from the specific country (Bosnia and Herzegovina) or the reports covering broader area (Balkan region).
}

INTERSECTIONS. EAST EUROPEAN JOURNAL OF SOCIETY AND POLITICS, 7(2): 49-72. 
from 2016 until the first few months of 2020 differ significantly in regard to their methodology, sources and outlook. Most of the reports, especially older ones, are based primarily on the direct contact of the group members with people who were pushed back (e.g., Banich, 2016a; 2016b; Inicijativa Dobrodošli!, 2017a; No Name Kitchen etc., 2018; 2019). Some are a combination of different sources (personal or other groups written or audio recordings of testimonies, media sources, reports of the authorities, other grassroots reports, human rights organization reports, etc.) (Incijativa Dobrodošli! etc., 2017b; 2017c; Info Kolpa, 2019; Border Violence Monitoring Network, 2019; 2020a; 2020b). Some were published once (e.g., Info Kolpa, 2019), while most of them occasionally (e.g., Incijativa Dobrodošli! etc., 2017a; 2017b; 2017c; Are you Syrious etc., 2018; Border Violence Monitoring Network etc., 2020), others regularly and monthly (No Name Kitchen etc., 2018; 2019; Border Violence Monitoring Network 2019; 2020a; 2020b).

The oldest reports were focused on publishing individual accounts-so-called testimonies or individual cases of pushbacks. They were included in the reports as appendixes to the core text (overview or analysis of the situation) of the report (e.g., Are you Syrious etc., 2018; Banich et al., 2016b) or they were the core of the reports. For example, monthly pushback reports, one of the long-running report publications (No Name Kitchen etc., 2018; 2019; Border Violence Monitoring Network, 2019; Border Violence Monitoring Network, 2019; 2020a; 2020b), in the first years were structured as collections of individual reports of pushbacks (No Name Kitchen etc., 2018; 2019), which will be discussed in more detail later in the text.

Finally, pushback reports were for a long time minimalistic in layout or in the paratextual (Genette, 1997) sense. The oldest reports usually had only the title of the publication, and the author or name of the group (source) (Inicijativa Dobrodošli! etc., 2017a; 2017b; 2017c; No Name Kitchen etc., 2018). Changes in the structure and layout or paratext of reports were followed by the shifts in the distribution, from minimal, internal distribution, to wide distribution via web, social media, email newsletter, maps and so on.

\section{Reporting pushbacks in a humanitarian and human rights perspective}

The beginnings of the grassroots reporting of pushbacks from Croatia (e.g., Banich et al., 2016a; Moving Europe, 2016a) can easily be seen as a continuation of the work of older activists from European anti-racist and pro-migrant initiatives oriented toward denouncing and challenging discriminatory, securitized and violent European migration policies. However, this was not necessarily the case with grassroots pushback reports published after the closure of the corridor. In fact, for many grassroots groups involved since then, reporting was a reaction to the brutality of the context in which they in the first place intervened with the idea of emergency assistance and essential humanitarian support. As the webpage of one of the groups exemplifies, the group 'began as a loose, self-organized group of people who in 2015 decided to respond to the humanitarian crisis by providing direct assistance,' but after some time in the field, the group started to develop projects in three different directions: humanitarian, political education and border violence monitoring. ${ }^{5}$ The founding narratives of other groups also mention this transformation of initial

See https://rigardu.de/en/aboutus/

INTERSECTIONS. EAST EUROPEAN JOURNAL OF SOCIETY AND POLITICS, 7(2): 49-72. 
humanitarian impulses and grassroots organizing into active confrontation and denunciations of violence. As, for example, mentioned by this group:

\begin{abstract}
born on February 3rd, 2017 in Belgrade. At that moment, the driving forces of the project, started to provide food and kitchen resources in order to cover, at least partially, the basic needs of all the refugees who lived in the old barracks of the train station. In collaboration with them, we got to distribute more than 500 meals per day, in a time period where the temperature dropped to -20 degrees. ${ }^{6}$
\end{abstract}

After several months this group moved out from Belgrade to the border area, where they organized diverse assistance for people on the move, as well 'engaged in the collection of testimonies from victims of border violence,' since 'the violent pushback and collective expulsion of people on the move is a daily occurrence in the area. To this end, certain volunteers from No Name Kitchen publish a monthly report on the situation with the testimonies of victims of this abuse."

In general, reporting in this context often figures as an outcome or byproduct of some other activity, most often it is done in parallel with providing basic aid: distributing food and clothes, providing showers, emergency medical help, etc. In accordance with this, the social media posts of this and other groups engaged in reporting alternate information about distribution of aid and expansion of border violence. ${ }^{8}$ In some instances reporting is not parallel with distributing aid, but with providing independent information for people on the move's or phone, email, or personal mediation between the migrants and the police organized to prevent pushback (Info Kolpa, 2019, p. 2; Are you Syrious etc., 2018, pp. 6-7).

Although this parallel providing basic help and challenging the authorities may at first sight seem dissonant with the modern official humanitarian imperatives of neutrality, impartiality and independence (see e.g., Barnett, 2011), it is not new in a humanitarian context. Quite the contrary, blending between providing aid and denouncing violence is one of the hallmarks of new forms of humanitarianism, influenced, among all, by the human rights discourse that dominated the moral sphere of the liberal international order of the late 20th century (Barnett, 2011, pp. 195-212). As summarized by Didier Fassin, 'publicly bearing witness of suffering and injustice is precisely what departs the first (International Red Cross) and second (Doctors without Borders, Doctors of the World) ages of humanitarianism' (2008, p. 555). Witnessing (témoignage), contested as a practice even within the MSF itself becomes a humanitarian 'duty' in that context (Redfield, 2013, p. 110). More precisely, 'historically, the emergence of the second age of humanitarianism, with "French doctors" returning from the war in Biafra, was a reaction to the silence of the Red Cross, wedded to its principle of neutrality. Testimony in favor of the victims becomes, for MSF and even more for Médecins du monde, a key dimension of their action' (Fassin, 2007, p. 516). Nevertheless, as MSF workers themselves insisted, witnessing is a secondary effect of humanitarian medical action, 'an essential byproduct, but a byproduct nonetheless' (Redfield, 2013, p. 110), as it is reporting for many grassroots groups discussed here. In this vein, these groups' engagement in reporting seems not as contradictory to humanitarian assistance, but in a way provoked by that assistance and even a necessary precondition for fur-

\footnotetext{
See https://www.nonamekitchen.org/en/

See http://www.nonamekitchen.org/en/what-do-we-do/

See https://www.facebook.com/NoNameKitchenBelgrade

See http://moving-europe.org/
}

INTERSECTIONS. EAST EUROPEAN JOURNAL OF SOCIETY AND POLITICS, 7(2): 49-72. 
ther provision of that assistance. As mentioned before, for solidarity-driven groups-and this is how most involved groups self-define or represent themselves ${ }^{10}$-reporting comes as a form of non-complying with the context in which they participate by the logic of humanitarian involvement. It is a way of self-distancing from re-production of borders in, what is termed in the literature, humanitarian borderwork (Pallister-Wilkins, 2017) or humanitarian border (Walters, 2011).

Besides humanitarian endeavors, grassroots pushback reports are comparable with human rights engagements. More precisely, they evoke comparison with human rights reports which, since the 1960s when Amnesty International pioneered their use, evolved into a distinct discursive genre (Buzzi, 2017). Similarities between grassroots pushback reports discussed here and human rights reports published by human rights organizations can be observed on the level of the terminology of the grassroots reports (their referring to human rights violations, collective expulsions, degrading treatment); the focus on the legal framework and argumentation, especially in the more recent reports (e.g., Border Violence Monitoring Network et al., 2020; Border Violence Monitoring Network, 2019; 2020a; $2020 \mathrm{~b}$ ); and on their general structure and layout. Far from a minimalistic graphic design, more recent reports often have discernible cover illustration, a designed layout, table of content and pagination. In fact, the writing style and graphic design of most of the recent pushback reports examined here (e.g., Border Violence Monitoring Network, 2020a; 2020b; Border Violence Monitoring Network et al., 2020) seem closer to the traditional genre of human rights reports than to the older reports of the same groups. Some of them have almost the canonical structure of human rights reports, described in literature (Cohen, 1996) as expressing concerns about the situation, stating the problem, setting the context, defining sources and methods, detailed allegations, an overview of international and domestic law and required actions or recommendations..$^{11}$ In sum, as many human rights reports, the most recent pushback reports are almost exclusively structured as overviews and analyses of the situation and of violations of human rights.

\footnotetext{
See https://www.nonamekitchen.org/en/, https://rigardu.de/en/aboutus/, Bužinkić 2018 etc.

11 Pushbacks came into the focus of human rights organizations reporting only relatively recently with new millennia and the expansion and brutalization of that bordering practice. In the human rights field, pushback reports were first addressed together with other human rights violations regarding right to international protection most often concerning the situation in Greece (Pro Asyl etc., 2007; see Norwegian Association for Asylum Seekers etc., 2009). Some of these reports were written in methodologically innovative ways, as already addressed in the literature (see Cabot, 2016). With series of reports about pushbacks at sea conducted by Italy, primary to Libya in the first decade of the 21st century (Human Rights Watch, 2006; 2009), pushbacks were recognized as recurrent and widespread violations of international and national law. In parallel, pushbacks conducted outside so-called pushback operations at the open sea also came into the fore of human rights reports, for example pushbacks from Greek land and sea borders to Turkey (Pro Asyl, 2007; Human Rights Watch, 2008) or pushbacks from Italy to Greece (Tsapopoulou et al., 2012). In the next decade pushbacks, still not always called as such, were promoted into the distinct subject of human right organizations reports, first in connection to the situation at the Aegean Sea and Greek land borders (Pro Asyl, 2013; Amnesty International, 2013; 2014a) and after in Bulgaria (Human Rights Watch, 2014), Hungary, North Macedonia, Serbia (Amnesty International, 2015), Spain (Amnesty International, 2015) or in relation to the restrictive and violent European border policies in general (Amnesty International, 2014b).
}

INTERSECTIONS. EAST EUROPEAN JOURNAL OF SOCIETY AND POLITICS, 7(2): 49-72. 


\section{Individual accounts of pushbacks between factual and contextual}

As mentioned before, grassroots pushback reports were not always structured as overviews or analyses of the situation and of human right violations. When the corridor was active and in the years after, individual accounts of pushbacks dominated the production of grassroots reports (e.g., Banich et al., 2016a; 2016b; No Name Kitchen etc., 2018; 2019; Are you Syrious et al., 2018). In fact, monthly pushback reports were for a long time (until December 2018 almost exclusively, and until April 2019 predominantly) structured as collections of individual reports or individual accounts of pushbacks. Their cumulative structure was highlighted already in their title as Illegal Push-backs [Pushbacks] and Border Violence Reports (No Name Kitchen et al, 2018). However, individual accounts included in those reports varied radically from one monthly report to another as well as within the same monthly reports. Roughly, it seems possible to discern two opposing tendencies of individual pushback accounts representation in these monthly collections of reports.

First, there is a tendency for the description of the individual pushback to be more factually, or even forensically founded, and action/incident-oriented, with simple, mostly one-dimensional and schematic structures, which consist of a departure, apprehension by the police, police misdoings, and pushback to the place where the report is made (e.g., No Name Kitchen etc., 2018, August, report 5 and 25, October, report 18). Additionally, this tendency of representation of individual accounts of pushbacks has distinctive characteristics including a persistent presentation of people who report about their experience of a pushback as anonymous even when the name is an element of a standardized form for reporting pushbacks (see e.g., No Name Kitchen etc., 2018, October, report 19), as well as the use of more formal language and technical terms such as 'respondent' (see e.g., No Name Kitchen etc., 2018, September, reports 14 and 17; 2019, February, report 1.9), 'victim' (e.g., No Name Kitchen etc., 2018, [August], report 25 and 28, September, report 4) and 'interviewee' (see e.g., No Name Kitchen etc., 2018, December, 1.13; 2019, January, reports 1.7, 1.9, 2.3). From the narratological perspective (Genette, 1980), individual pushback accounts which represent more factual and action/incident-oriented reporting of individual pushbacks, usually have an extradiegetic (external to the narrative) and heterodiegetic (absent from the narrative) narrator that 'takes over' the narrative from the person who is pushed back and attaches it to a supposedly neutral, external instance.

In contrast to this tendency, some individual accounts included in the monthly collections of pushback reports seem to belong to more personal, migrant and context-oriented reporting tendency. They are characterized by the predominant use of a personal names for the people who are pushed back, as well as extensive reference to the verbal and nonverbal interaction between volunteer/activist and that person (e.g., 'At the end of the interview, Saraj told me' / 'Adan told me' / 'Rakan told me'; 'Fajsan told me' / 'Amin told me' / 'Mohamad told me' / 'Mohamad showed me' / 'Adnann described the attack in the following way,' No Name Kitchen etc., 2018, October). Furthermore, this migrant-oriented tendency of representation of individual pushback accounts is characterized by extensive use of direct speech, as illustrated in the following passages:

In the morning, Saad, 36 years old man from Palestine came to the showers close to the informal camp in Velika Kladuša, where the No Name Kitchen provides showers. Saad could barely walk and looked disoriented and tired. He sat down on a chair and explained that he was brutally attacked by the Croatian police at the Bosnian border

INTERSECTIONS. EAST EUROPEAN JOURNAL OF SOCIETY AND POLITICS, 7(2): 49-72. 


\begin{abstract}
the previous night, when he and other 16 persons were being deported back to Bosnia: 'They made a half circle in front of the car and one by one called out of the car and beating him. There were children and woman. They also beat the woman because she tried to hide her phone under her clothes and they found out, so they hit her by a baton. Her children and we could see it. Children were crying. But the police did not care. They kept telling me: "Fuck you, fuck your mother," and after shouting at us, "Heidi, go back to Bosnia!" It was horrible, they were deporting us around 3 am and for three or four hours after, we were searching for each other in a forest. They were beating also an old man who was there with us and now has broken finger. [...] Do you have a cigarette? I have money [pulling ten marks out of his pocket], but I cannot go to the supermarket because I feel so dizzy and tired. I keep vomiting blood. I can't eat anything as I vomit it out. I think I may have maybe internal bleeding from so many kicks into my body (Saad).'
\end{abstract}

Later in the afternoon, I met another four men who were together with Saad deported back to Bosnia. Mahmoud, 35 years old Syrian who could speak fluent English, explained to me what happened to him and his friends the previous night at the Croatian-Bosnian border. (e.g., No Name Kitchen etc., 2018, October, report 7)

This and other more contextual and migrant-oriented individual pushback accounts include descriptions of the process of documenting and reporting the pushback ('In the morning, Saad, 36 years old...'; 'Later in the afternoon, I met...'), as well as an individual account of the pushback presented as direct speech ('They made a half circle...') and related to the individual with a name (here 'Saad') (e.g., No Name Kitchen etc., 2018, August, report 3). Individuality of the personal account of the pushback and the process of its documentation within this tendency is furthermore acknowledged by the use of direct speech even within direct speech (e.g., 'They kept telling me: "Fuck you, fuck your mother"), linguistic plurality of the context ('Heidi' as distorted pronunciation and/or transcription of hajde meaning 'go' in Croatian) and registering the nonverbal aspects of communication ('[pulling ten marks out of his pocket]'). Finally, reports belonging to this representational framework have two levels of narration and two narrators, one which narrates documenting the pushback and the other that narrates the pushback. The first narrator deals with the context, atmosphere, and events related to the process of documenting and the interaction with the person who was pushed back, as well as with the narrator's reception of person pushed back narrative. Here we are dealing with a narrator involved in a narrative as a character: the volunteer/activist who is documenting the pushback. The second narrator is, in narratological terminology (Genette, 1980), intradiegetic, embedded into the narrative of the first narrator. This narrator is homodiegetic or a narrator-character: the person who experienced the pushback.

\title{
6 Grassroots pushback reporting and ethnography
}

The interest of some of the individual reports or accounts in various contexts and perspectives, and, in general, their inclination toward what is called thick description in anthropology (Geertz, 1973, pp. 3-30), calls for further investigation of the parallels between grassroots pushback reporting and ethnography.

According to Heath Cabot, it is the story, the interview, and the case that can be seen as 'some perhaps obvious examples' of meeting points between ethnographic research

INTERSECTIONS. EAST EUROPEAN JOURNAL OF SOCIETY AND POLITICS, 7(2): 49-72. 
and advocacy work, including reporting (Cabot, 2016, p. 8). ${ }^{12}$ Indeed, as formulated by one of the groups at issue here, reporting pushbacks is driven by the idea to bring 'often forgotten stories to public attention and demand that these practices stop immediately. ${ }^{13}$ According to the perspective of the members of another group, publishing individual accounts of pushbacks is based on the idea, not 'to speak for victims' but to 'propel their voices and stories to the widest possible audience and build the case for an adherence to international law and safe sanctuary for all refugees' (Campbell \& Augustová, 2018). By highlighting stories or individual accounts, grassroots groups employ, in William Walters' terms, 'epistemic strategy' that at the same time eventually assign " voice" to subjects who are presumed to have no place as political subjects in official debates' and 'acts as a tactic of empathy' (Walters, 2011, p. 152).

Moreover, in the case of grassroots pushback reports, empathy is not only related to the modes of the reception of the reports, but it tackles also the methodology. Besides as a mode of reception, empathy functions here as the 'ethnographic empathy', meaning inclination toward understanding perspective of others, and interest in the other and in his or her story per se, often represented by the extensive or exclusive use of direct speech, as in the example of Saad's retelling of the pushback he experienced, cited in the previous section. By mobilizing direct speech for the presentation of individual accounts, these reports advocate for the autonomy of people who experienced pushbacks. The idea is that the protagonists, or, as described by members of one of the groups involved in reporting pushbacks, 'the victims should have the autonomy to share their experiences' and that reporters should 'respect that narrative, giving respondents the opportunity to tell their part within this story of borders (a simple objective so often neglected in the media coverage of contestation sites such as national frontiers)' (Campbell \& Augustová, 2018). From a linguistic perspective, the use of direct speech implies perceiving 'another's utterance as a compact, indivisible, fixed, impenetrable whole' (Voloshinov, 1973, p. 128). This approach is echoed in pushback monthly reports or collections of individual pushback accounts (No Name Kitchen et al., 2018; 2019), as well as in the reports published during the period of the Balkan refugee corridor (e.g., Banich 2016a; Moving Europe 2016b; 2016c) which encompass individual accounts of pushbacks in form of testimonies, uninterrupted direct speech even when they are derived from interviews.

The commitment of many, mostly older, grassroots pushback reports to document and present individual accounts of pushbacks in broadly speaking integral form, as individual accounts, stories or cases, brings into the discussion their parallels with ethnographic fieldnotes. At first, parallels between fieldnotes and individual reports seem obscured by an extensive reliance of individual accounts of pushbacks on 'truth' or 'evidence' devices represented by the attached medical documentation, photos of injuries or geolocations, as well as, tabular presentation of the individual accounts of pushbacks (in fact summaries of interviews) in monthly reports (No Name Kitchen etc., 2018; 2019). However, the representation of individual accounts of pushbacks in the format of a table with fixed sections (Type of the incident, Location, Victims, Date and time, Details, Description of the incident, Information about the perpetrators, Injuries and medical treatment, Photos of injuries; No

12 Cabot also points to differences between advocacy and ethnographic research in refugee context, such as critical perspective of ethnographic work vs. reports work to defend existing knowledge frameworks or ethnographic valuing of inconsistency vs. reports striving to consistency (see Cabot, 2016, p. 8).

13 See https://www.borderviolence.eu/about/

INTERSECTIONS. EAST EUROPEAN JOURNAL OF SOCIETY AND POLITICS, 7(2): 49-72. 
Name Kitchen etc., 2018, September) does not necessarily signal their incongruence with an ethnographic apparatus since tables based on the forms for gathering at least basic contextual data (about the informants, date and place etc.) were not so long-ago part of standard ethnographic fieldwork tools in some contexts (see Hameršak, 2012).

Finally, an overview of convergences between grassroots pushback reports and ethnography necessarily needs to tackle the issue of reporters' and interviewed migrants' (im)mobilities. As mentioned before, grassroots pushback reports examined here are very often based on the volunteer/activist leaving home, which is often located in one of the EU member states (Croatia, Slovenia, Germany, Italy etc.) to go to Serbia or Bosnia and Herzegovina, as the closest countries where people who are pushed back from EU reside and are prone to speak out. This constellation evidently strongly resonates with paradigmatic, although today more and more outdated, ethnographer's displacement. More striking convergences rise from the circumstances that reports are often based on the encounter of temporary immobilized migrants, with volunteers or activists who, as Ruben Andersson noticed regarding his research with Senegal's deportees, in a manner of prototypical ethnographer paradoxically 'came and went, taking their time and stories away with them' (Andersson, 2017, p. 91). Several reports based on the long-distance communication technologies and digital tools, exchange of phone text and email messages, online forms and calls eschew this type of relation characterized by the mobile reporters and immobile-returned or stuck-people on the move. One of them entails the immobility of both a reporter who stays at home and a correspondent in the camp (Inicijativa Dobrodošli, 2016) while others, written on the basis of exchanges of telephone messages between activists, police and people on the move, even reverse the above-described relationship (Info Kolpa, 2019). This report, namely, relies on the immobile activists who communicate from home with people on the move who, at the same time, struggle to maintain their mobility (Info Kolpa, 2019).

For groups situated at the outer fringes of the EU and now for years engaged in publishing regular monthly pushback reports, long-term, in continuity or periodical, presences in the field, another hallmark of ethnography, appears to be a crucial dimension of their reporting practice. As outlined in the discussion of the humanitarian background of grassroots pushback reports, reporters are, like ethnographers, engaged in participating in everyday realities of people who are excluded from the legal, political, and social order and routinely pushed back across borders from one state to another. Or, as it is explained in the introduction to one of the monthly pushback reports: 'The methodological process for these reports leverages the close social contact that we have as independent volunteers with refugees and migrants to monitor pushbacks from Croatia. When individuals return with significant injuries or stories of abuse, one of our violence reporting volunteers will sit down with the individuals to collect their testimonies' (No Name Kitchen etc., 2019, February). Testimonies are collected by the interviews done in a 'standardized framework' developed for the monthly pushback reports (No Name Kitchen etc., 2019, January), which in this context appears as the preferred method because the violence these reports strive to document is characterized by 'open aggression and assault' (Isakjee et al., 2020, p. 13) done far from the sight of reporters.

Finally, the (self)reflexive stances about production of pushback reports, such as those about reporting process cited above, together with the previously mentioned activists' reflections about activist tourist dimension of their work in Balkans, or, to introduce a new

INTERSECTIONS. EAST EUROPEAN JOURNAL OF SOCIETY AND POLITICS, 7(2): 49-72. 
example, activists' readiness to acknowledge that reports are not the 'most radical tool one can imagine' (Push-Back Map, s. a.) for challenging the system, open up further, and here concluding, lines of connection between these reports and ethnographic inquiries. These and others here not mentioned examples of self-reflection from relatively rich textual production of these groups or their members about their documenting and reporting work (Augustova \& Sapoch, 2020; Bužinkić, 2018; Bužinkić \& Avon, 2020; Campbell \& Augustová, 2018; Info Kolpa, 2020; Push-Back Map Collective, 2020) make reports and reporting close to para-ethnographic accounts. In other words, they position grassroots reports as, in the terms of Douglas Holmes and George Marcus, 'self-conscious critical faculty operating in diverse domains as a way of dealing with contradictions, exceptions, and facts that are fugitive, suggesting a social realm and social processes not in alignment with conventional representations and reigning modes of knowledge and analysis' (2008, p. 596; see Holmes \& Marcus, 2005). ${ }^{14}$

\section{Between supporting and reporting}

Although the fusion of bureaucratic technology such as reporting and spontaneous promigrant organizing may at first sight might seem incongruous, it fits well into the global documenting fever, which in a way haunts this article also-as suggested by the extensiveness of its bibliography. Far from being undervalued as a form of bureaucratic knowledge, documents, and documenting, including reports and reporting, are today embraced in different fields from arts and academia (see e.g., Kurtović, 2019) to grassroots pro-migrant initiatives.

Spontaneous pro-migrant groups and initiatives formed in the response to mobility breakthroughs of the restrictive EU border control regime in 2015 and 2016. They employed different methods and practices to support the people on the move and to challenge the inefficient, bureaucratized, discriminatory, and securitized modes of action of official, state, and humanitarian actors. Some practices that were developed in this framework of citizen engagements over time evolved into distinctive formats of response to the border restrictions, exclusions, and violence. One of them is still a lasting practice of reporting of pushbacks by grassroots groups active at different locations on the outskirts of the EU, in particular along the Balkan migratory pathway. By outlining the grassroots, self-organized, humanitarian, and human rights background of pushback reports and reporting practices related to Croatia, as well as their representational tendencies and further convergences with ethnographic inquiries, this paper hopefully sets a basic foundation for eventual future analysis of these reports as forms of textual struggles, as well as forms which not only resonate with ethnographic knowledge production, but also speak about the (self)positioning of that knowledge in the contemporary world.

14 Of course, self-reflective positioning, as when reports highlight that 'only small sample from the experience of [...] activists' which boosts concerns that 'the number of illegal and violent push backs is much higher' (Inicijativa Dobrodošli!, 2017a, s. p.; Are you Syrious et al., 2018), can be sometimes function as reassurance of the argument, but in this context it is more often functioning as a call for critical rethinking.

INTERSECTIONS. EAST EUROPEAN JOURNAL OF SOCIETY AND POLITICS, 7(2): 49-72. 


\section{Acknowledgement}

This work has been fully supported by the Croatian Science Foundation under the project ERIM - The European Irregularized Migration Regime at the Periphery of the EU: from Ethnography to Keywords (IP-2019-04-6642).

\section{References}

Agier, M. et al. (2019). The fungle: Calais's camps and migrants. Polity.

Andersson, R. (2019). From radar systems to rickety boats: Borderline ethnography in Europe's 'illegality industry'. In A. Eliot, R. Norum \& N. B. Salazar (Eds.), Methodologies of mobility: Ethnography and experiment (pp. 88-108). Berghahn Books.

Atkinson, P., Coffey, A., Delamont, S., Lofland, J. \& Lofland, L. (2007). Handbook of ethnography. Sage.

Augustová, K. \& Sapoch, J. (2020). Border violence as border deterrence condensed: Analysis of violent push-backs from the ground. movements: fournal for Critical Migration and Border Regime Studies, 5(1), 119-213. https://movements-journal.org/issues/08. balkanroute/12.augustova,sapoch-border-violence-as-border-deterrence.html Accessed: 25-09-2020.

Barnett, M. (2011). The empire of humanity: A history of humanitarianism. Cornell University Press.

Beznec, B., Speer, M. \& Stojić Mitrović, M. (2016). Governing the Balkan route: Macedonia, Serbia and European border regime. Rosa Luxemburg Stiftung Southeast Europe. https://www.rosalux.de/fileadmin/rls_uploads/pdfs/engl/Governing_the_Balkan_ Route.pdf Accessed: 18-09-2020.

Birey, T., Cantat, C., Mączyńska, E. \& Sevinin, E. (Eds.). (2019). Challenging the political across borders: Migrants' and solidarity struggles. Center for Policy Studies, Central European University. https://cps.ceu.edu/publications/books/challenging-politicalacross-borders-migrants-and-solidarity-struggles Accessed: 18-09-2020

Brković, Č. (2016). Depoliticization 'from below': Everyday humanitarianism in Bosnia and Herzegovina. Narodna umjetnost: Croatian Journal of Ethnology and Folklore Research, 53(1), 97-115. https://doi.org/10.15176/vol53no105

Brković, Č. (2017). Introduction. Vernacular \#humanitarianisms. Allegra Lab, 30 September. https://allegralaboratory.net/vernacular-humanitarianisms/ Accessed: 18-092020.

Brković, Č. (2020). Vernacular humanitarianism. In A. De Lauri (Ed.), Humanitarianism: Keywords (pp. 224-226). Brill. https://doi.org/10.1163/9789004431140_0104

Buzzi, C. (2017). The Human Rights Report as discursive genre: Evolving discourses in human rights activism in Myanmar/Burma 1988-2011. Alternatives: Global, Local, Political, 41(4), 214-230. https://doi.org/10.1177/0304375417714926

INTERSECTIONS. EAST EUROPEAN JOURNAL OF SOCIETY AND POLITICS, 7(2): 49-72. 
Bužinkić, E. (2018). Welcome to vs. Welcome through: Crisis mobilization and solidarity with refugees in Croatia as a transit country. In E. Bužinkić \& M. Hameršak (Eds.) Formation and disintegration of the Balkan refugee corridor: Camps, routes and borders in Croatian context (pp. 143-167). Institute of Ethnology and Folklore Research, Centre for Peace Studies, Faculty of Political Science University of Zagreb - Centre for Ethnicity, Citizenship and Migration, bordermonitoring.eu e.V. https://indd.adobe. com/view/301e48ae-2011-44e0-992c-789cd03f7669 Accessed: 03-10-2020.

Bužinkić, E. \& Avon, M. (2020). Pushback as a technology of crimmigration. In N. Kogovšek Šalamon (Ed.), Causes and consequences of migrant criminalization (pp. 157-170). Springer. https://doi.org/10.1007/978-3-030-43732-9_8

Bužinkić, E. \& Hameršak, M. (Eds.). (2018). Formation and disintegration of the Balkan refugee corridor: Camps, routes and borders in Croatian context. Institute of Ethnology and Folklore Research, Centre for Peace Studies, Faculty of Political Science University of Zagreb - Centre for Ethnicity, Citizenship and Migration, bordermonitoring.eu e.V. https://indd.adobe.com/view/301e48ae-2011-44e0-992c-789cd03f7669 Accessed: 03-10-2020.

Cabot, H. (2019). The European refugee crisis and humanitarian citizenship in Greece. Ethnos, 84(5), 747-771. https://doi.org/10.1080/00141844.2018.1529693

Campbell, S. \& Augustova, K. (2018). AYS Special: EU border violence (Update from BosnianCroatian border for September). https://medium.com/are-you-syrious/ays-special-euborder-violence-update-from-bosnian-croatian-border-fro-september-3f2a6227d 383 Accessed: 30-09-2020.

Cantat, C. (2015). Contesting Europeanism: Discourses and practices of promigrant organizations in the European Union. Ph.D. thesis, University of East London. http://roar. uel.ac.uk/4618/ Accessed: 20-08-2020.

Cantat, C. (2020). The rise and fall of migration solidarity in Belgrade. movements: fournal for Critical Migration and Border Regime Studies, 5(1), 97-122. https://movementsjournal.org/issues/08.balkanroute/05.cantat-the-rise-and-fall-of-migration-solidar ity-in-belgrade.html Accessed: 25-09-2020.

Cantat, C. \& Feischmidt, M. (2018). Conclusion: Civil involvement in refugee protectionReconfiguring humanitarianism and solidarity in Europe. In M. Feischmidt, P. Ludger \& C. Cantat (Eds.), Refugee protection and civil society in Europe (pp. 379-399). Palgrave. https://doi.org/10.1007/978-3-319-92741-1_14

Cohen, S. (1996). Government responses to Human Rights Reports: Claims, denials, and counterclaims. Human Rights Quarterly, 18(3), 517-543.

della Porta, D. (Ed.). (2018). Solidarity mobilizations in the 'refugee crisis': Contentious moves. Palgrave.

El-Shaarawi, N. \& Razsa, M. (2019). Movements upon movements: Refugee and activist struggles to open the Balkan route to Europe. History and Anthropology, 30(1), 91112. https://doi.org/10.1080/02757206.2018.1530668

INTERSECTIONS. EAST EUROPEAN JOURNAL OF SOCIETY AND POLITICS, 7(2): 49-72. 
Fassin, D. (2007). Humanitarianism as a politics of life. Public Culture, 19(3), 499-520. https://doi.org/10.1215/08992363-2007-007

Fassin, D. (2008). The humanitarian politics of testimony: Subjectification through trauma in the Israeli-Palestinian conflict. Cultural Anthropology, 23(3), 531-558. https://doi. $\operatorname{org} / 10.1111 / \mathrm{j} .1548-1360.2008 .00017 . x$

Fechter, A.-M. \& Schwittay, A. (2019). Citizen aid: Grassroots interventions in development and humanitarianism. Third World Quarterly, 40(10), 1769-1780. https://doi.org/ $10.1080 / 01436597.2019 .1656062$

Feischmidt, M., L. Pries \& Cantat, C. (Eds.). (2019). Refugee protection and civil society in Europe. Palgrave.

Gabrielsen Jumbert, M. (2020). Advocacy. In A. De Lauri (Ed.), Humanitarianism: Keywords (pp. 3-5). Brill. https://doi.org/10.1163/9789004431140_003

Genette, G. (1980). Narrative discourse: An essay in method. Cornell University Press. Translated by J. E. Lewin.

Genette, G. (1997). Paratexts: Thresholds of interpretation. Cambridge University Press. Translated by J. E. Lewin.

Grubiša, I. (2018). Us and Them? Cultural anthropological rethinking of the fieldwork experience in Slavonia. In E. Bužinkić \& M. Hameršak (Eds.), Formation and disintegration of the Balkan refugee corridor: Camps, routes and borders in Croatian Context (pp. 63-86). Institute of Ethnology and Folklore Research, Centre for Peace Studies, Faculty of Political Science University of Zagreb - Centre for Ethnicity, Citizenship and Migration, bordermonitoring.eu e.V. https://indd.adobe.com/view/301e48ae-2011-44 e0-992c-789cd03f7669 Accessed: 03-10-2020.

Geertz, C. (1973). The interpretation of cultures: Selected essays. Basic Books.

Hamann, U. \& Karakayali, S. (2016). Practicing Willkommenskultur: Migration and solidarity in Germany. Intersections: East European Journal of Society and Politics, 2(4), 69-86. https://doi.org/10.17356/ieejsp.v2i4.296

Hameršak, M. (2012). Zapisi o zapisima. Rukopisne zbirke Maje Bošković-Stulli [Notes on notes: Maja Bošković Stulli's collection of manuscripts]. Književna republika, 1011-12, 107-116.

Hameršak, M. \& Pleše, I. (2017). Winter reception and transit center in the Republic of Croatia: An ethnographic view of the Slavonski Brod refugee camp. Narodna umjetnost: Croatian fournal of Ethnology and Folklore Research, 54(1), 101-127. https://doi. org/10.15176/vol54no106

Hameršak, M. \& Pleše, I. (2018a). In the shadow of the transit spectacle. In M. Rajković Iveta, P. Kelemen \& D. Župarić-Iljić (Eds.), Contemporary migration trends and flows on the territory of Southeast Europe (pp. 145-159). FF Press Filozofski fakultet Sveučilišta u Zagrebu, Odsjek za etnologiju i kulturnu antropologiju.

INTERSECTIONS. EAST EUROPEAN JOURNAL OF SOCIETY AND POLITICS, 7(2): 49-72. 
Hameršak, M. \& Pleše, I. (2018b). Confined in movement: The Croatian section of the Balkan refugee corridor. In E. Bužinkić \& M. Hameršak (Eds.), Formation and disintegration of the Balkan refugee corridor: Camps, routes and borders in Croatian context (pp. 9-41). Institute of Ethnology and Folklore Research, Centre for Peace Studies, Faculty of Political Science University of Zagreb - Centre for Ethnicity, Citizenship and Migration, bordermonitoring.eu e.V.https://indd.adobe.com/view/301e48ae-201144e0-992c-789cd03f7669 Accessed: 03-10-2020.

Hess, S. \& Kasparek, B. (2017). De- and restabilising Schengen: The European border regime after the summer of migration. Cuadernos Europeos de Deusto, (56), 47-77. https://doi.org/10.18543/ced-56-2017pp47-77

Holmes, D. R. \& Marcus, G. (2008). Para-ethnography. In L. M. Given (Ed.), The Sage encyclopedia of qualitative research methods (pp. 595-597). Sage.

Holmes, D. R. \& Marcus, G. (2005). Cultures of expertise and the management of globalization: Toward the re-functioning of ethnography. In A. Ong \& S. J. Colier (Eds.), Global assemblages: Technology, politics, and ethics as anthropological problems (pp. 235-252). Wiley-Blackwell.

Hromadžić, A. (2020). Notes from the field: 'Migrant crisis' in Bihać, Bosnia and Herzegovina. movements: Journal for Critical Migration and Border Regime Studies, 5(1), 163180. https://movements-journal.org/issues/08.balkanroute/08.hromadzic--notesfrom-the-field.html Accessed: 27-09-2020.

Info Kolpa (2020). Report on illegal practices of collective expulsion at the SlovenianCroatian border and struggles against it. movements: fournal for Critical Migration and Border Regime Studies, 5(1), 233-242. https://movements-journal.org/issues/08. balkanroute/13.info-kolpa--report-on-illegal-practices-of-collective-expulsion-atthe-slovenian-croatian-border-and-struggles-against-it.html Accessed: 26-09-2020.

Isakjee, A., Davies, T., Obradović-Wochnik, J. \& Augustová, K. (2020). Liberal violence and the racial borders of the European Union. Antipode: A Radical fournal of Geography, 52(6), 1751-1773. https://doi.org/10.1111/anti.12670

Jambrešić Kirin, R. \& Škokić, T. (2018). The shopping center of abnormal normality: Ethnography of the distribution tent in the refugee camp in Slavonski Brod. In E. Bužinkić, \& M. Hameršak (Eds.), Formation and disintegration of the Balkan refugee corridor: Camps, routes and borders in Croatian context (pp. 87-108). Institute of Ethnology and Folklore Research, Centre for Peace Studies, Faculty of Political Science University of Zagreb - Centre for Ethnicity, Citizenship and Migration, bordermonitoring.eu e.V. https://indd.adobe.com/view/301e48ae-2011-44e0-992c-789cd03f7669 Accessed: 03-10-2020.

Jovanović, T. (2020). Transformations of humanitarian aid and response modes to migration movements: A case study of the Miksalište Center in Belgrade. movements: Fournal for Critical Migration and Border Regime Studies, 5(1), 125-147. https://movementsjournal.org/issues/08.balkanroute/06.jovanovic-teodora-transformations-of-human itarian-aid-and-response.html Accessed: 27-09-2020.

INTERSECTIONS. EAST EUROPEAN JOURNAL OF SOCIETY AND POLITICS, 7(2): 49-72. 
Kallius, A., Monterescu, D. \& Kumar Rajaram, P. (2016). Immobilizing mobility: Border ethnography, illiberal democracy, and the politics of the 'refugee crisis' in Hungary. American Ethnologist, 43(1), 1-13. https://doi.org/10.1111/amet.12260

Kurnik, A. (2015). 'Hvala, ker odpirate Evropo' ['Thank you for opening up Europe']. Časopis za kritiko znanosti, domišljijo in novo antropologijo, 262, 225-240.

Kurnik, A. \& Razsa, M. (2020). Reappropriating the Balkan route: Mobility struggles and joint-agency in Bosnia and Herzegovina. Dve domovini / Two Homelands, 52, 7-23. https://doi.org/10.3986/dd.2020.2.01

Kurtović, L. (2019). An archive to build a future: The recovery and rediscovery of the history of socialist associations in contemporary Bosnia-Herzegovina. History and Anthropology, 30(1), 20-46. https://doi.org/10.1080/02757206.2018.1532893

Lyons, M. (2010). A new history from below? The writing culture of ordinary people in Europe. History Australia, 7(3), 59.1-59.9. https://doi.org/10.2104/ha100059

Moving Europe (2016a). The 'Humanitarian Corridor'. In Summer of Migration. http://moving-europe.org/wp-content/uploads/2016/09/Part-6-The-Humanitarian-Corridor.pdf Accessed: 18-09-2020.

McGee, D. \& Pelham, J. (2018). Politics at play: Locating human rights, refugees and grassroots humanitarianism in the Calais Jungle. Leisure Studies, 37(1), 22-35. https://doi. org/10.1080/02614367.2017.1406979

Milan, C. (2019). Refugees at the gates of the EU: Civic initiatives and grassroots responses to the refugee crisis along the Western Balkans route. Fournal of Balkan and Near Eastern Studies, 21(1), 43-60. https://doi.org/10.1080/19448953.2018.1532686

Pallister-Wilkins, P. (2017). Humanitarian borderwork. In C. Günay \& N. Witjes (Eds.), Border politics: Defining spaces of governance and forms of transgression (pp. 85-103). Springer. https://doi.org/10.1007/978-3-319-46855-6_6

Pozniak, R. (2019). Pomoć ili biznis? Transformacija humanitarnog rada u slavonskobrodskom kampu za izbjeglice / Aid or business? The transformation of humanitarian work in the refugee camp in Slavonski Brod. Studia Ethnologica Croatica, 31(1), 4666; 67-86. https://doi.org/10.17234/SEC.31.2

Pozniak, R. (2020). Affective labor within the local humanitarian workscape. movements: Fournal for Critical Migration and Border Regime Studies, 5(1), 55-73. https://movements-journal.org/issues/08.balkanroute/03.pozniak-affective-labor-within-the-local-humanitarian-workspace.html Accessed: 25-09-2020.

Push-Back Map Collective (2020). The Push-Back Map mapping border violence in Europe and beyond: A collective self-reflection. movements: fournal for Critical Migration and Border Regime Studies, 5(1), 197-204. https://movements-journal.org/issues/08. balkanroute/10.pbm-collective-the-push-back-map.html Accessed: 03-10-2020.

INTERSECTIONS. EAST EUROPEAN JOURNAL OF SOCIETY AND POLITICS, 7(2): 49-72. 
Push-Back Map (s. a.). Push Back Map: A grassroots mapping tool against pushbacks and the global border regime. https://pushbackmap.org/wp-content/uploads/2020/02/0616-19-Activist-Manual.pdf Accessed: 27-09-2020.

Redfield, P. (2013). The ethical journey of Doctors without Borders. University of California Press.

ReflActionist Collective (2016). Beyond voluntourism and holidarity? White German activist on the 'Balkanroute' - (self)reflections. https://reflactionistcollective.noblogs.org/ post/2016/06/18/beyond-voluntourism-and-holidarity/ Accessed: 30-09-2020.

Riles, A. (2006). Introduction: In Response. In A. Riles (Ed.), Documents: Artifacts of Modern Knowledge (pp. 1-38). University of Michigan.

Rozakou, K. (2016). Socialites of solidarity: Revisiting the gift taboo in times of crises. Social Anthropology, 24(2), 185-199. https://doi.org/10.1111/1469-8676.12305

Rozakou, K. (2017). Solidarity \#humanitarianism: The blurred boundaries of humanitarianism in Greece. Etnofoor, 29(2), 99-104.

Sandri, E. (2018). 'Volunteer humanitarianism': Volunteers and humanitarian aid in the Jungle refugee camp of Calais. Journal of Ethnic and Migration Studies, 44(1), 66-80. https://doi.org/10.1080/1369183X.2017.1352467

Schneider, F. \& Kopp. H. (2017). A brief history of No Border Network. http://www.tacticalmediafiles.net/articles/3332/A-Brief-History-of-the-Noborder-Network Accessed: 04-08-2020.

Schulpen, L. \& Huyse, H. (2017). Editorial. Citizen initiatives for global solidarity: The new face of European solidarity. Forum for Development Studies, 44(2), 163-169. https://doi. org/10.1080/08039410.2017.1306956

Stierl, M. (2019). From sympathy to solidarity. In C. Jacob, S. Kron \& W. Christoph (Eds.), The atlas of migration: Facts and figures about people on the move (pp. 46-47). Rosa Luxemburg Foundation. https://www.rosalux.de/fileadmin/rls_uploads/pdfs/sonst publikationen/atlasofmigration2019_II_web_191023.pdf Accessed: 27-09-2020.

Stojić Mitrović, M., Ahmetašević, N., Beznec, B. \& Kurnik, A. (2020). Dark sides of Europeanization: Serbia, Bosnia and Herzegovina and the European border regime. Rosa Luxemburg Stiftung and Inštitut Časopis za kritiko znanosti. https://www.rosalux.rs /sites/default/files/publications/MITROVIC_Dark_Sides_of_EU_.pdf Accessed 02-102020.

Šelo Šabić, S. \& Borić, S. (2016). At the gate of Europe: A report on refugees on the Western Balkan route. Friedrich Erbert Stifung. http://www.irmo.hr/wp-content/uploads/2016 /05/At-the-Gate-of-Europe_WEB.pdf Accessed: 23-09-2020.

Vandevoordt, R. (2019). Subversive humanitarianism: Rethinking refugee solidarity through grass-roots initiatives. Refugee Survey Quarterly, 38, 245-265. https://doi.org/ 10.1093/rsq/hdz008

INTERSECTIONS. EAST EUROPEAN JOURNAL OF SOCIETY AND POLITICS, 7(2): 49-72. 
Voloshinov, V. N. (1973). Marxism and the philosophy of the language. Seminar Press. Translated by L. Matejka \& I. R. Titunik.

Walters, W. (2006). No border: Games with(out) frontiers. Social fustice, 33(1), 21-39.

Walters, W. (2011). Foucault and frontiers: Notes on the birth of the humanitarian border. In U. Bröckling, S. Krassman \& T. Lemke (Eds.), Governmentality: Current issues and future challenges (pp. 138-164). Routledge.

Župarić-Iljić, D. \& Valenta, M. (2019). Opportunistic humanitarianism and securitization discomfort along the Balkan corridor: The Croatian experience. In M. Feischmidt, L. Pries \& C. Cantat (Eds.), Refugee protection and civil society in Europe (pp. 129-160). Palgrave Macmillan. https://doi.org/10.1007/978-3-319-92741-1_5

\section{Reports}

Amnesty International (2013). Frontier Europe: Human rights abuses on Greece's border with Turkey. https://www.amnesty.org/download/Documents/12000/eur250082013 en.pdf Accessed: 2-08-2020.

Amnesty International (2014a). Greece. Frontier of hope and fear: Migrants and refugees pushed back at Europe's borders. https://www.amnesty.org/download/Documents/ 8000/eur250042014en.pdf Accessed: 2-08-2020.

Amnesty International (2014b). The human cost of Fortress Europe: Human rights violations against migrants and refugees at Europe's border. https://www.amnesty.ch/de/themen/ asyl-und-migration/festung-europa/dok/2015/die-kampagne-sos-europa/bericht-thehuman-cost-of-fortress-Europe Accessed: 3-08-2020.

Amnesty International (2015). Fear and fence: Europe's approach to keeping refugees at bay. https://www.amnesty.org/download/Documents/EUR0325442015ENGLISH.PDF Accessed: 3-08-2020.

Are you Syrious, Center for Peace Studies, Inicijativa Dobrodošli \& No Name Kitchen (2018). Fourth report on illegal pushbacks of refugees from the republic of Croatia in the period from fune 2017 to February 2018. https://www.cms.hr/system/article_document /doc/504/Fourth_Report_on_Illegal_Pushbacks.pdf Accessed: 26-09-2020.

Banich, S., Gerbig, L. \& Homberger, A. (2016a). Report on systemic police violence and pushbacks against non-SIA people conducted by Croatian authorities. http://movingeurope.org/report-on-push-backs-and-police-violence-at-the-serbo-croatian-border2/ Accessed: 27-09-2020.

Banich, S., Brnardić, S., Hameršak, M., Kekuš, S., Marčetić, I., Piškor, M \& Sindičić, M. (2016b). Report on systemic human rights violations by the Croatian authorities in the closed parts of the winter reception and transit centre in Slavonski Brod. http://movingeurope.org/wp-content/uploads/2016/03/Slavonski-Brod.pdf Accessed: 27-09-2020.

INTERSECTIONS. EAST EUROPEAN JOURNAL OF SOCIETY AND POLITICS, 7(2): 49-72. 
Belgrade Centre for Human Rights, Macedonia Young Lawyers Association, with the support of Oxfam International (2017). A dangerous 'Game': The pushback of migrants, including refugees, at Europe's borders. https://www.oxfam.org/sites/www.oxfam.org/ files/file_attachments/bp-dangerous-game-pushback-migrants-refugees-060417-en _0.pdf Accessed: 3-08-2020.

Border Violence Monitoring Network (s. a). Testimonies database. https://www.borderviolence.eu/violence-reports/ Accessed: 3-03-2021.

Border Violence Monitoring Network (2019). Illegal pushbacks and border violence reports / Illegal push-backs and border violence reports / Border violence and push-back reports / Border violence report. https://www.borderviolence.eu/category/monthlyreport/ Accessed: 20-07-2020.

Border Violence Monitoring Network, Center for Peace Studies, Society for Psychological Assistance \& Welcome Initiative (2020). Pushback report on children and unaccompanied children in Croatia. https://www.cms.hr/system/article_document/doc/647/ Pushback_report_on_children_and_unaccompanied_children_in_Croatia.pdf Accessed: 04-10-2020.

Border Violence Network (2020a). Illegal pushbacks and border violence reports. https:// www.borderviolence.eu/category/monthly-report/ Accessed: 20-07-2020.

Border Violence Network (2020b). Balkan Region. https://www.borderviolence.eu/category/monthly-report/ Accessed: 20-07-2020.

Documenta - centar za suočavanje s prošlošću (2015). Humanost u trenucima izbjegličke krize. Izvještaj o potrebama i radu s izbjeglicama [Humanity in moments of refugee crisis: Report on the needs of and work with refugees]. http://www.documenta.hr/assets/ files/objave/2015-06/Humanost-u-trenucima-izbjeglicke-krize-Izvjestaj.pdf Accessed: 25-09-2018.

European Economic and Social Committee (2016). EESC fact-finding missions on the situation of refugees, as seen by civil society organisations. Mission report-Croatia. 12 and 13 fanuary 2016. https://www.eesc.europa.eu/resources/docs/croatia_migration-mission-report_en.pdf Accessed: 26-09-2020.

Human Rights Watch (2006). Stemming the flow: Abuses against migrants, asylum seekers and refugees. Part III. https://www.hrw.org/reports/2006/libya0906/libya0906webwcover.pdf Accessed: 03-08-2020.

Human Rights Watch (2008). Stuck in a revolving door: Iraqis and other asylum seekers and migrants at the Greece/Turkey entrance to the European Union. https://www.refworld. org/cgi-bin/texis/vtx/rwmain?page $=$ search \&docid $=492$ e6c $622 \&$ skip $=0 \&$ query $=$ pushback\&searchin=fulltext\&sort=date Accessed: 02-08-2020.

Human Rights Watch (2009). Pushed back, pushed around: Italy's forced return of boat migrants and asylum seekers, Libya's mistreatment of migrants and asylum seekers. https://www.hrw.org/sites/default/files/reports/italy0909webwcover_0.pdf Accessed: 02-08-2020.

INTERSECTIONS. EAST EUROPEAN JOURNAL OF SOCIETY AND POLITICS, 7(2): 49-72. 
Human Rights Watch (2014). 'Containment plan': Bulgaria's pushbacks and detention of Syrian and other asylum seekers and migrants. https://www.hrw.org/report/2014/04/ 28/containment-plan/bulgarias-pushbacks-and-detention-syrian-and-other-asylumseekers Accessed: 03-08-2020.

Human Rights Watch (2017). Croatia: Asylum seekers forced back to Serbia. https://www. hrw.org/news/2017/01/20/croatia-asylum-seekers-forced-back-serbia Accessed: 2709-2020.

Info Kolpa (2019). Report on illegal practices of collective expulsion at the Slovenian-Croatian border. https://push-forward.org/sites/default/files/2019-08/Report\%20on\%20illegal $\% 20$ practice $\% 20$ of $\% 20$ collective $\% 20$ expulsion $\% 20$ on\%20slovene-croatian $\% 20$ border. pdf Accessed: 26-09-2020.

Inicijativa Dobrodošli (2016). Bez doma i slobode. Izbjeglice u Hrvatskoj. Zidne novine. [Without home and freedom: Refugees in Croatia. Newsboard.] https://www.cms.hr/ system/article_document/doc/282/Zidne_novine_Inicijative_Dobrodosli.pdf Accessed: 30-09-2020.

Inicijativa Dobrodošli! \& Are you Syrious (2017a). Report on illegal and forced push backs of refugees from the Republic of Croatia. http://welcome.cms.hr/wp-content/uploads/ 2017/01/REPORT-ON-ILLEGAL-AND-FORCED-PUSH-BACKS-OF-REFUGEESFROM-THE-REPUBLIC-OF-CROATIA.pdf Accessed: 27-09-2020.

Inicijativa Dobrodošli! \& Are you Syrious (2017b). The second report on unlawful and forced push backs of refugees from the Republic of Croatia. http://welcome.cms.hr/wpcontent/uploads/2017/08/THE-SECOND-REPORT-ON-UNLAWFUL-AND-FORCEDPUSH-BACKS-OF-REFUGEES-FROM-THE-REPUBLIC-OF-CROATIA.pdf Accessed: 27-09-2020.

Inicijativa Dobrodošli! \& Are you Syrious (2017c). Report on the new wave of violence against refugees on Croatian borders. http://welcome.cms.hr/wp-content/uploads/ 2017/05/REPORT-ON-THE-NEW-WAVE-OF-VIOLENCE-AGAINST-REFUGEES-ONCROATIAN-BORDERS.pdf Accessed: 27-09-2020.

Larsen, M., Demir, E. \& Horvat, M. (2016). Humanitarian responses by local actors: Lessons learned from managing the transit of migrants and refugees through Croatia. IIED Working Paper. http://pubs.iied.org/pdfs/10795IIED.pdf Accessed: 26-09-2020.

Médecins Sans Frontières (2017). Games of violence: Unaccompanied children and young people repeatedly abused by EU member state border authorities. https://www.msf.org/ sites/msf.org/files/serbia-games-of-violence-3.10.17.pdf Accessed: 03-08-2020.

Moving Europe (2016b). Report on pushbacks from Slovenia to Serbia. http://moving-europe. org/report-on-push-backs-from-slovenia-to-serbia/ Accessed: 27-09-2020.

Moving Europe (2016c). Report on human rights violations and push-backs against people travelling towards Germany conducted by Austrian, Slovenian and Croatian authorities. http://moving-europe.org/report-on-human-rights-violations-and-push-backs-

INTERSECTIONS. EAST EUROPEAN JOURNAL OF SOCIETY AND POLITICS, 7(2): 49-72. 
against-people-travelling-towards-germany-conducted-by-austrian-slovenian-andcroatian-authorities/ Accessed: 27-09-2020.

Moving Europe (2016d). Report on the unlawful pushbacks from FYROM/Macedonia to Greece on 14 March 2016. http://moving-europe.org/wp-content/uploads/2016/04/ Report-on-push-backs-from-Macedonia-to-Greece.pdf Accessed: 27-09-2020.

Moving Europe (2016e). Bordered lives-unbound violence. http://moving-europe.org/ bordered-lives-unbound-violence/\#fnref-3617-6 Accessed: 30-09-2020.

No Name Kitchen etc. (2018). Illegal pushbacks and border violence reports / Illegal pushbacks and border violence reports. https://www.nonamekitchen.org/en/violencereports/ Accessed: 20-07-2020.

No Name Kitchen et al. (2019). Illegal push-backs and border violence reports. https://www. nonamekitchen.org/en/violence-reports/ Accessed: 20-07-2020.

Norwegian Organisation for Asylum Seekers, Norwegian Helsinki Committee \& AITIMA (2009). Out the back door: The Dublin II regulation and illegal deportations from Greece. https://www.statewatch.org/media/documents/news/2009/oct/greece-illegal-deportations-report.pdf Accessed: 02-08-2020.

Push-Back Map (s. a.). https://pushbackmap.org/ Accessed: 03-03-2021.

Pro Asyl (2013). Pushed back: Systematic human rights violations against refugees in the Aegean sea and the Greek-Turkish land border. https:/www.proasyl.de/wp-content/ uploads/2015/12/PRO_ASYL_Report_Pushed_Back_english_November_2013.pdf Accessed: 02-08-2020.

Pro Asyl \& Group of Lawyers for the Rights of Refugees and Immigrants Athens (2007). 'The truth may be bitter but it must be told': The situation in the Aegean and the practices of the Greek coast guard. https://www.statewatch.org/media/documents/news/ 2015/aug/greece-pro-asly-report-coast-guards.pdf Accessed: 02-08-2020.

Refugees, Supporters and Buscrew Moving-Europe (2016). Croatia: Slavonski Brod Transit Camp for Migrants and Refugees. http://moving-europe.org/croatia-slavonski-brodtransit-camp-for-migrants-and-refugees/ Accessed: 27-09-2020.

Tsapopoulou, K. Tzeferakou, M. \& Stroux, S. (2012). Human cargo: Arbitrary readmissions from the Italian sea ports to Greece. https:/www.proasyl.de/wp-content/uploads/2015/ 12/PRO_ASYL_Report_Human_Cargo_Arbitrary_Readmissions_from_Italy_to_ Greece_July_2013.pdf Accessed: 02-08-2020.

INTERSECTIONS. EAST EUROPEAN JOURNAL OF SOCIETY AND POLITICS, 7(2): 49-72. 